\title{
SISTEM PEMANTAUAN KESEHATAN LOBSTER (LHMS) DENGAN MACHINE LEARNING
}

\author{
Ari Purno Wahyu', Muhammad Benny Chaniago(), Murnawan ${ }^{3)}$, R.A.E. Virgana),Cecep Kurnia ${ }^{5)}$ \\ ${ }^{1)}$ Informatika Universitas Widyatama \\ Jl. Cikutra No.204A, Cibeunying Kidul, Bandung, 40125 \\ ${ }^{2,3,4)}$ Sistem Informasi Universitas Widyatama \\ Jl. Cikutra No.204A, Cibeunying Kidul, Bandung, 40125 \\ e-mail: ari.purno@widyatama.ac.id ${ }^{1)}$,benny.chaniago@widyatama.ac.id ${ }^{2)}$, \\ murnawan@widyatama.ac.id ${ }^{3)}$,rae.virgana@widyatama.ac.id ${ }^{4}$, cecep.kurnia@nusaputra.ac.id ${ }^{5)}$ \\ * Korespondensi: e-mail: cecep.kurnia@nusaputra.ac.id ${ }^{5)}$
}

\begin{abstract}
ABSTRAK
Lobster merupakan hewan yang hidup di perairan dangkal. Hewan ini memiliki nilai jual yang sangat tinggi, oleh karena itu perlu ditingkatkan produksinya untuk proses peningkatan ekspor dan untuk memenuhi kebutuhan pasar. Di Indonesia sistem budidaya lobster dilakukan di lepas pantai dengan menggunakan bantuan keramba. Sistem ini masih dilakukan secara tradisional dan lobster yang dijual bervarietas. Nilai jual lobster akan meningkatkan jika lobster tersebut berukuran besar dan dalam kondisi hidup, sehingga cara pengawasan dan peningkatan hewan ini perlu dilakukan secara spesifik dan dilakukan secaraserius. Monitoring perkembangan lobster dengan cara ini memiliki beberapa kelemahanya itu sistem montoring yang sulit karena hanya bisa dilakukan pada saat-saat tertentu dan tidak terpantau selama 24 jam, kadang air dan pusaran arus laut yang berubah-ubah sehingga berpengaruh besar pada perkembangan lobster. Perkembangan lobster dengan keramba juga saat ini berbahaya yang dipengaruhi oleh suhu air yang dapat menyebabkan lobster tersebut kekurangan makanan. Solusi masalah tersebut adalah dengan menggunakan bantuan teknik komputerisasi dengan Teknik machine learning yang dipergunakan untuk memonitoring pertumbuhan lobster tanpa mengganggu habitat lobster tersebut. Dengan bantuan teknik machine learning bisasecara langsung menampilkan gambar visual keadaan lobster tersebut dibawah laut atau bisa dipergunakan untuk monitoring lobster pada tangki atau kolam. Tingkat monitoring dan pemberian pakan bisa dilakukan secara otomatis. Identifikasi dan monitoring lobster dengan teknik computer vision memiliki tingkat akurasi hingga $90 \%$.
\end{abstract}

Kata Kunci: Perkembangbiakan Lobster, Machine learning, Monitoring

\begin{abstract}
Lobster is an animal that lives in shallow water. This animal has a very high selling value, therefore production needs to be increased for the process of increasing exports and to meet market needs. In Indonesia the lobtser cultivation system is carried out offshore using the help of a cage. This system is still carried out traditionally and lobsters are sold in various varieties. The sale value of a lobster will increase if the lobster is large and in living conditions, so the way to monitor and enhance these animals needs to be done specifically and seriously. Monitoring the development of lobsters in this way has several disadvantages, namely a difficult monting-ing system because it can only be done at certain times and not monitored for 24 hours, sometimes the water and watershed changes so that it has a major influence on the development of lobsters. . The development of lobster with cages is also currently dangerous which is influenced by water temperature which can cause the lobster to lack food. The solution to these problems is to use computerized engineering assistance with machine learning techniques that are used to monitor lobster growth without disturbing the lobster habitat. With the help of machine learning techniques can directly display visual images of the lobster under the sea or can be used for monitoring lobsters in tanks or ponds. The level of monitoring and feeding can be done automatically. Identification and monitoring of lobsters with computer vision techniques has an accuracy rate of up to $90 \%$.
\end{abstract}

Keywords: Lobster breeding, Machine learning, Monitoring

\section{PENDAHULUAN}

Sistem identifikasi dan proses pengawasan lobster sangat penting karena dengan mengetahui identitas dan jenis lobster kita dapat mengetahui sifat, jenis dan habitat asli tempat lobster tersebut hidup. Sistem identifikasi sebelumnya dilakukan dengan cara memberikan label pada lobster yang berfungsi untuk mengidentifikasi dengan mata telanjang jenis dan tipelobster. Data identifikasi tersebut bisa dijadikan sebagai bahan acuan untuk merekayasa dan membuat tempat lobster tersebut berkembangbiak sehingga keadaan habitat asli lobster bisa terjaga. Sistem monitoring dengan machine learning dirasa sangat diperlukan karena kemampuan dan keterbatasan manusia serta mengawasi dan mengidentifikasi objek yang dipengaruhi oleh kondisi alam. Penggunaan machine learning ini memungkinkan adanya informasi dan data yang terintegrasi serta kecocokan data monitoring antara tempat perkembangbiakan yang satu dengan yang lainnya. 


\section{LANDASAN TEORI}

Beberapa penelitian dibidang perikanan telah menentukan dan menggunakan sebuah pola dalam memecahkan sebuah masalah untuk mendeteksi dan membedakan objek, proses dengan membedakan warna yang bisa digunakan untuk klasifikasi dan dipergunakan pada bidang ilmiah lainnya. Sebagai contoh sistem deteksi ikan masih menjadi objek penelitian yang sangat menarik dan teknologi ini terus diaplikasikan secara realtime[1].

Pada teknik image processing ada yang disebut dengan teknik segmentasi warna dimana teknik tersebut mempresentasikan cara pandang manusia dengan teknik secara terkomputerisasi dan sistem ini masuk kedalam sebuah proses analisis yang penting terutama dalam mengenali sebuah pola warna. Tekstur sendiri memegang peranan penting pada sebuah proses klasifikasi. Metode ini sudah menjadi bahan penelitian yang lengkap dan cocok untuk mengenali pola dan metode ini banyak digunakan oleh para peneliti [2].

Sistem monitoring hewan merupakan sebuah kegiatan untuk melihat sebuah respon hewan terhadap keadaan lingkungan sekitar. Perubahan tersebut dapat membagi dan mendata pertumbuhan binatang yang nantinya data tersebut dipergunakan untuk mengawasi keberlangsungan hewan. Dengan berkembangnya sistem komputerisasi maka dibuatlah sistem monitoring dengan menggunakan sebuah metode baru dengan bantuan teknik komputer yang dapat dilakukan untuk kegiatan research dan komersial [3].

Tujuan lain dari sistem monitoring hewan adalah banyaknya species hewan yang dilindungi, sehingga diperlukan sebuah pengawasan yang dapat dilakukan pada hewan. Alat monitoring dapat disimpan di tempat terbuka seperti dalam kolam Smart Cage. Beberapa penelitian proses pengawasan dapat dilakukan secara realtime. Monitoring dapat dilakukan untuk mengukur populasi hewan pada sebuah habitat tertentu. Sistem monitoring dapat menggunakan kamera yang disimpan langsung di alam liar. Penelitian sebelumnya menggunakan data dari rekaman dan sistem monitoring dapat dilakukan secara jarak jauh [4][5].

Data dari sistem monitoring dapat dipergunakan untuk melihat tingkah laku dan klasifikasi sebuah hewan yang ada dialam liar. Prosesnya adalah dengan membandingkan sifat hewan dengan data yang semuanya disimpan dalam satu dataset. Pengambilan gambar langsung di alam liar memiliki beberapa kendala, kendala tersebut yaitu mulai dari tingkat pencahayaan yang kurang jelas, rekaman yang rusak, dan data yang tidak terkirim pada server dataset [6].

Pada sistem monitoring, kamera memegang sebuah peranan penting yang berfungsi untuk mengambil sebuah objek yang nantinya akan dipergunakan untuk membaca sebuah informasi. Kamera yang dipergunakan yaitu kamera dari jenis thermal imaging, cara kerja kamera tersebut adalah dengan membaca pantulan energi dan cahaya serta menampilkannya menjadi sebuah perubahan warna suhu yang merupakan pantulan dari radiasi, semakin tinggi tingkat pencahayaan semakin tinggi radiasi yang dipancarkan [7].

Pergerakan sebuah hewan erat hubungannya dengan monitoring kesehatan hewan tersebut, sistem pergerakan dapat menampilan sebuah informasi hewan sehat atau tidak. Proses ini dapat dilakukan dengan menggunakan bantuan komputer dan tidak dapat dilakukan dengan mata telanjang serta sistem ini perlu dilakukan penelitian secara berkelanjutan [8].

Pengukuran sifat dan perilaku hewan air pernah dilakukan pada jenis ikan sarden dan rockfish yang disimpan didalam tangki akuarium yang dipasang dibawah tanki. Data hewan tersebut prosesnya terus bergerak dengan menggunakan metode teknologi DFIS (Dual Frequency Identification Sonar) [9].

Untuk inputan sebuah data dapat menggunakan sebuah data image, data sebelumnya sudah dikonversi menjadi abu-abu dan ukuran pada gambar bisa dibuat default atau kembali dibuat secara standar, karena ukuran gambar yang besar akan memperlama proses pembacaan data dan kurang efisien dimana kepadatan pada sebuah pixel dari image yang terbesar menjadi yang terkecil. Langkah ini digunakan agar data menjadi lebih cepat dibaca oleh sistem dan resolusi diperkecil secara teratur [10].

Teknologi pemantau perilaku hewan air sebelumnya dipergunakan untuk memonitoring kehidupanikan,teknologi computer vision dikombinasikan dengan teknik optik dan akustik atau menggunakan teknologi sonar. Keuntungan teknologi ini adalah alat bisa disimpan secara jarak jauh dan bisa dilakukan secara realtime [11].

Tujuan penggunaan data image adalah sebagai data latih agar semakin banyak data yang dipergunakan makin tinggi pula akurasi pembacaan data. Proses ini mampu meminimalisir kesalahan pembacaan data antara input dan ouput data yang dihasilkan algoritma neural network dan dengan nilai "K" sebagai vektor keluaran[12].

$$
E(w)=\frac{1}{K \times N} \sum_{k=1}^{K} \sum_{n=1}^{N_{L}}\left(y_{n}^{k}-d_{n}^{k}\right)^{2}
$$

Keterangan :

Nilai $\mathrm{K}$ tersebut adalah membaca gradient, yang nantinya nilai tersebut akan digunakan sebagai inputan pada neural network. Algoritma ini memaksimalkan fungsi nilai energi pada perubahan data yang pada tiap image 
berdasarkan nilai gradientnya. Nilai ykn adalah nilai dengan network. $\mathrm{K}$ adalah nomer dari sebuah image dan ouput nilai vektor, dengan nilai X k sebagai data training data image dan nilai Dk sebagai perhitungan nilai vektor.

\section{METODE PENELITIAN}

Jika Pada pengujian kali ini, kamera menjadi alat yang memiliki peranan penting yang menentukan tingkat akurasi. Tahapan deteksi tersebut sebagai alat sortasi dengan tahapan sebagai berikut:

\section{Deteksi image}

Proses deteksi image adalah proses pengambilan gambar lobster langsung dengan menggunakan kamera yang bisa dipasang dibawah kolam. Fungsi kamera tersebut adalah untuk mendeteksi aktivitas lobster langsung dibawah air. Kamera yang digunakan bisa berupa kamera jenis underwater surveillance dan pengambilan gambar dilakukan secara realtime.

\section{Background subtraction}

Pengambilan gambar sangat dipengaruhi oleh faktor lain yaitu tingkat pencahayaan, kurangnya tingkat pencahayaan akan mempengaruhi akurasi image yang sangat dipengaruhi oleh objek yang lain.

\section{Deteksi tepi}

Pada bagian ini proses deteksi tepi dipergunakan untuk mengukur ukuran lobster mulai dari kepala bagiandepan hingga ekor. Identitas dan ciri lobster bisa ditentukan dengan deteksi tepi ini.

\section{Deteksi warna}

Jenis lobster mampu dibedakan dengan menggunakan sistem deteksi warna. Sistem ini mendeteksi lobster melalui corak yang ada pada kulit lobster.

\section{Klasifikasi citra}

Pada bagian ini merupakan proses akhir dimana aplikasi akan menampilkan data secara visual jenis dan warna lobster.

\subsection{Hasil}

Pada hasil pengujian sistem ini akan menampilkan jenis lobster serta tingkat akurasi. Sistem ini diharapkanakan membantu memonitor tumbuh kembang lobster dengan lebih presisi, sehingga jenis lobster bisa terbaca yang selanjutnya bisa digunakan untuk mengatur jenis pakan dan pengaturan tempat lobster tersebut hidup.

\section{IMPLEMENTASI SISTEM}

Pada pengujian ini sistem alat monitoring menggunakan bantuan kamera yang tersimpan pada bagian atas kolam atau tersimpan langsung dibawah kolam. Kameramen gambil data secara realtime, data tersebut kemudian disimpan pada data server dan membandingkannya dengan data training, data lobster tersebut kemudian diproses dengan teknik image processing, sistem pengukuran adalah dari tiga jenislobtser yang berbeda.

Sistem monitoring dapat dilakukan secara realtime dan data akan diproses per frame. Algoritma yang digunakan adalah metode machine learning dengan algoritma neural network.

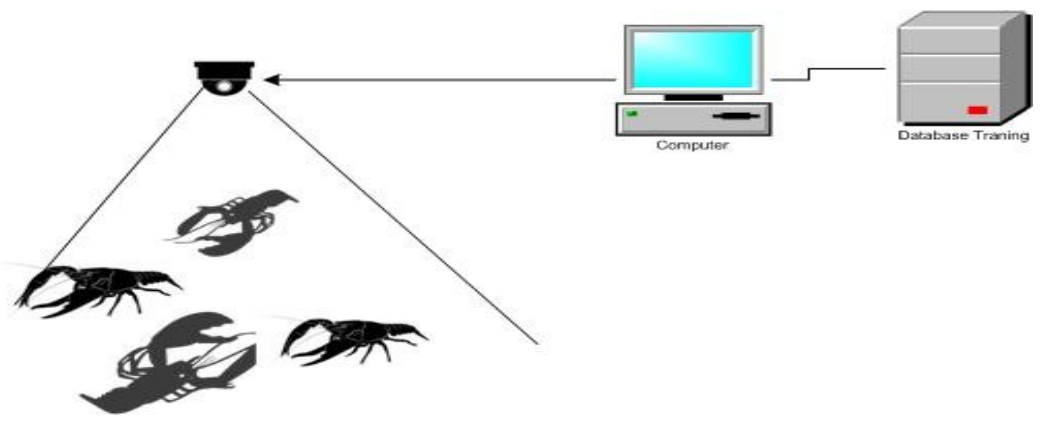

Gambar 1. Perancangan Alat Monitoring Lobster

Pada pengujian kali ini dilakukan proses identifikasi jenis lobster serta ukuran lobster. Sistem identifikasi dilakukan secara otomatis dengan sample lobster yang dilakukan secara acak. 


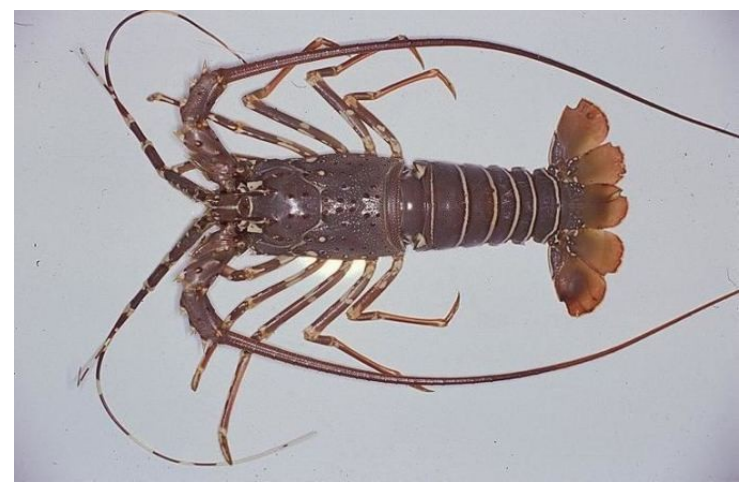

Keterangan :

Gambar 2. Lobster Jenis Pakistan (Panulirus Polypagus)

Pada gambar 2 adalah sample jenis lobster Pakistan dengan warna agak kemerahan dan terdapat garis hitam dengan warna hitam.

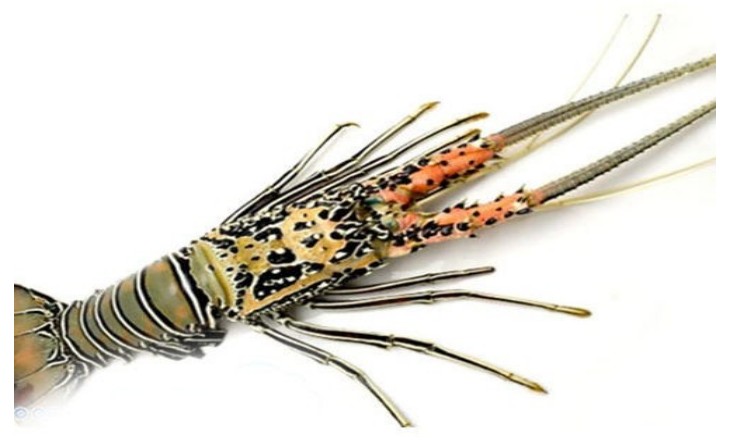

Gambar 3. Lobster Bambu

\section{Keterangan :}

Pada gambar 3 adalah lobster jenis bambu dengan ciri khas berwarna hijau dan pada bagian ekor serta warna irisan berwarna biru dan warna pada bagian kepala berwarna merah.

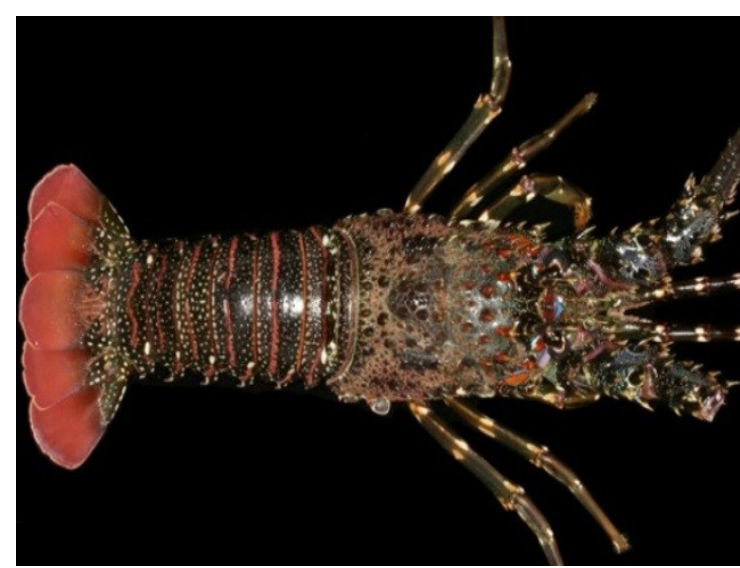

Gambar 4. Lobster Pasir

\section{Keterangan :}

Pada gambar 4 adalah jenis lobster pasir dengan ciri berwarna merah dan kehitaman

Pada pengujian kali ini lobster menggunakan beberapa sample yang diambil secara acak yang digunakan untuk mengidentifikasi jenis lobster yang digunakan sebagai data latih. 


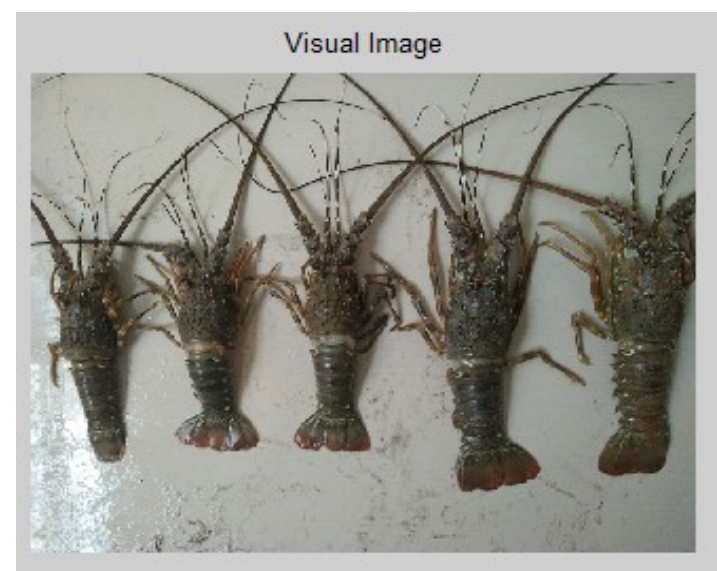

Gambar 5. Jenis Lobster

\section{Keterangan :}

Data pada gambar 5 disamping adalah proses pengambilan jenis lobster yang diambil sebagai data sample dari ukuran yang terkecil hingga yang terbesar.

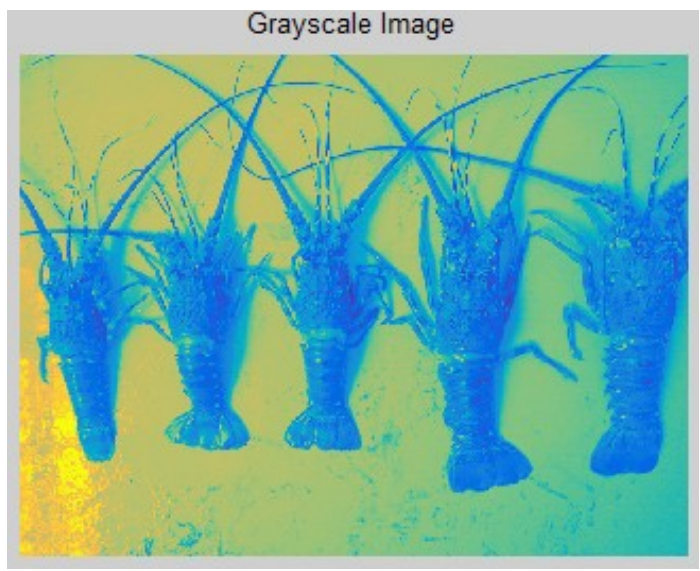

Gambar 6. Konfigurasi Greyscale

\section{Keterangan :} lobster.

Pada gambar 6 bagian sample adalah sebuah proses deteksi lobster melalui identifikasi warna menentukan jenis

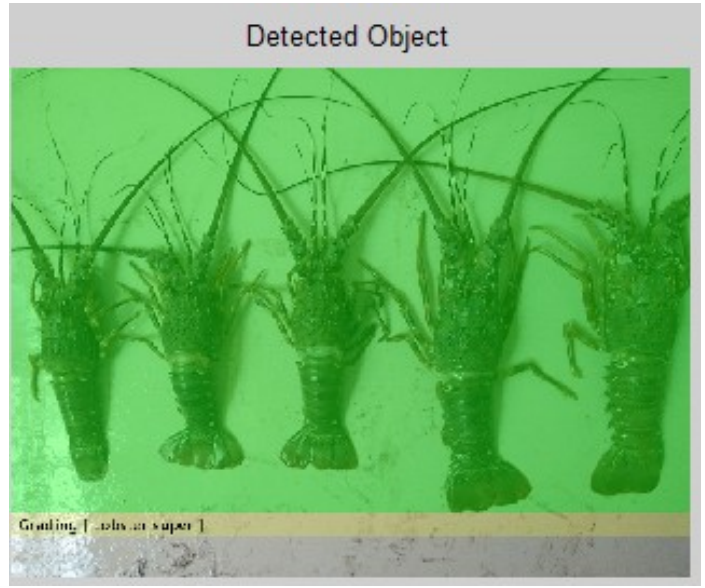

Gambar 7. Identifikasi Objek

\section{Keterangan :}

Pada gambar 7 adalah proses pembacaan data lobster untuk membedakan objek utama dengan background, da ri metode tersebut sistem pembacaan lobster akan lebih tinggi dan objek pengganggu atau noise dapat dikurangi. 


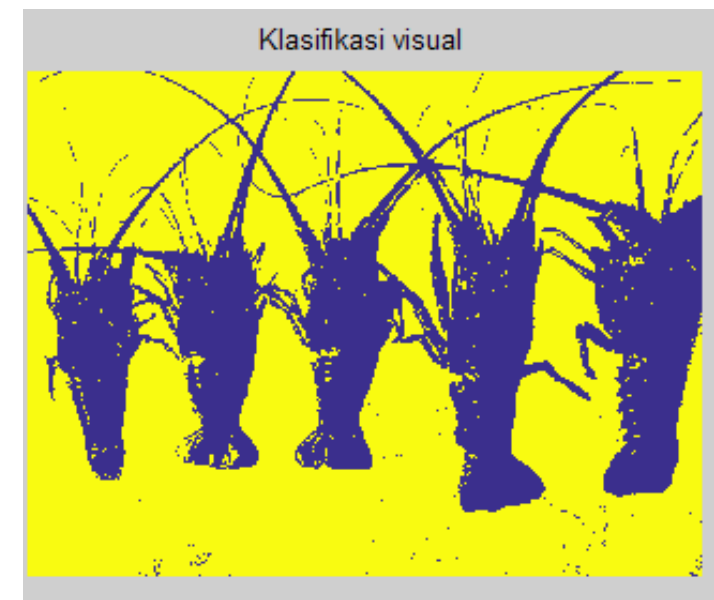

Gambar 8. Penggunaan Background Subtraction

\section{Keterangan :}

Pada gambar 8 adalah proses membacaukuran lobster dengan teknik background subtraction, metode pengukuran yang digunakan untuk membaca ukuran lobster pada bagian tubuh lobster bentuk ciri pada setiap lobster.

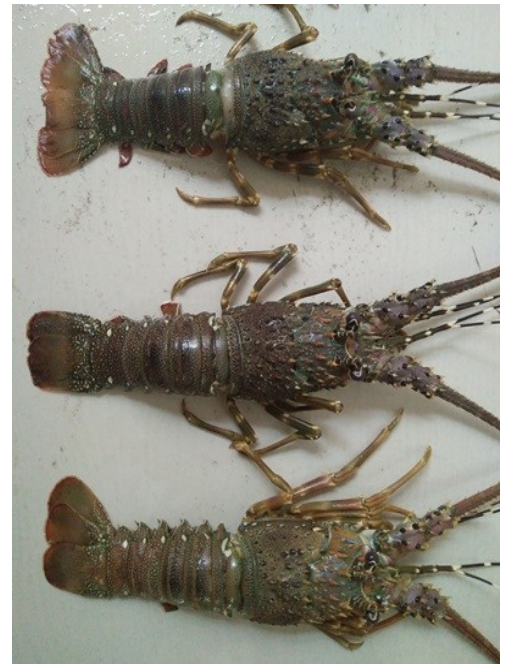

Gambar 9. Indentifikasi Tiga Jenis Lobter

\section{Keterangan :}

Pada gambar 9 sample adalah pengujian sistem dengan menggunakan tiga lobster yang berbeda, sistem pengujian dilakukan menggunakan algoritma computer vision.

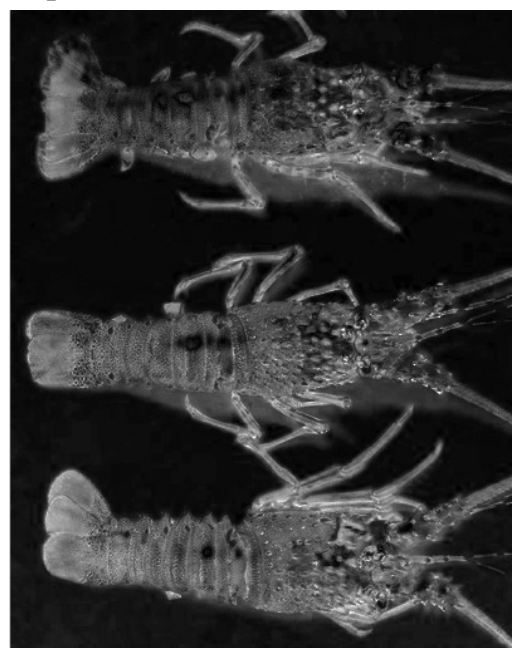

Gambar 10. Deteksi Tepi 


\section{Keterangan :}

Pada gambar 10 pengujian dengan teknik background subtraction, dengan menampilkan deteksi tepi. Metode ini untuk menampilkan fitur dan bentuk yang unik pada tiap lobster. Algoritma yang digunakan adalah deteksi tepi.

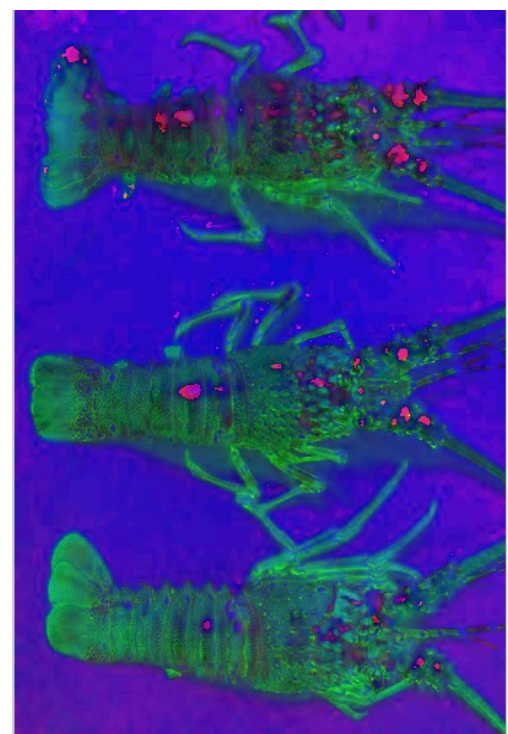

Gambar 11. Indentifikasi Ciri Unik Lobster

\section{Keterangan :}

Pada gambar 11 diatas sistem secara otomatis dapat mengenali jenis lobster. Pada tampilan visual terlihat bahwa lobster akan memantulkan warna yang unik dengan warna dan bentuk bintik kemerahan. Bintik kemerahan paling banyak terlihat pada lobster jenis pasir dari kepala hingga ujung ekor, sedangkan pada bagian tengah ada lobster pakistan dengan ciri unik bintik merah pada bagian tengah ekor.Pada gambar yang terakhir adalah ciri lobster bambu dengan ciri khas bintik merah agak kecil yaitu empat pada bagian kepala dan satu pada bagian ekor.

Tabel 1. Hasil Pengujian

\begin{tabular}{|c|c|}
\hline Jenis Lobster & $\begin{array}{c}\text { Ciriunik yang dite- } \\
\text { mukan }\end{array}$ \\
\hline & $\begin{array}{l}\text { Bintik yang dibaca se- } \\
\text { cara visual oleh kom- } \\
\text { puter, warna merah ter- } \\
\text { letak pada bagian kepala } \\
\text { dan pada ekor bawah } \\
\text { serta pada bagian ujung, } \\
\text { dan merupakan ciri } \\
\text { utama pada lobster pasir }\end{array}$ \\
\hline & $\begin{array}{l}\text { Pada gambar disamping } \\
\text { adalah bintik merah } \\
\text { pada lobster bambu, } \\
\text { dengan ciri bintik merah } \\
\text { pada badan bagian ten- } \\
\text { gah dan bintik merah } \\
\text { pada bagian kepala, ciri } \\
\text { utama pada lobster pak- } \\
\text { istan }\end{array}$ \\
\hline & $\begin{array}{l}\text { Pada gambar disamping } \\
\text { adalah ciri yang ada } \\
\text { pada lobster bambu den- } \\
\text { gan ciri bintik merah } \\
\text { pada bagian kepala, ciri } \\
\text { utama pada lobster } \\
\text { bambu }\end{array}$ \\
\hline
\end{tabular}




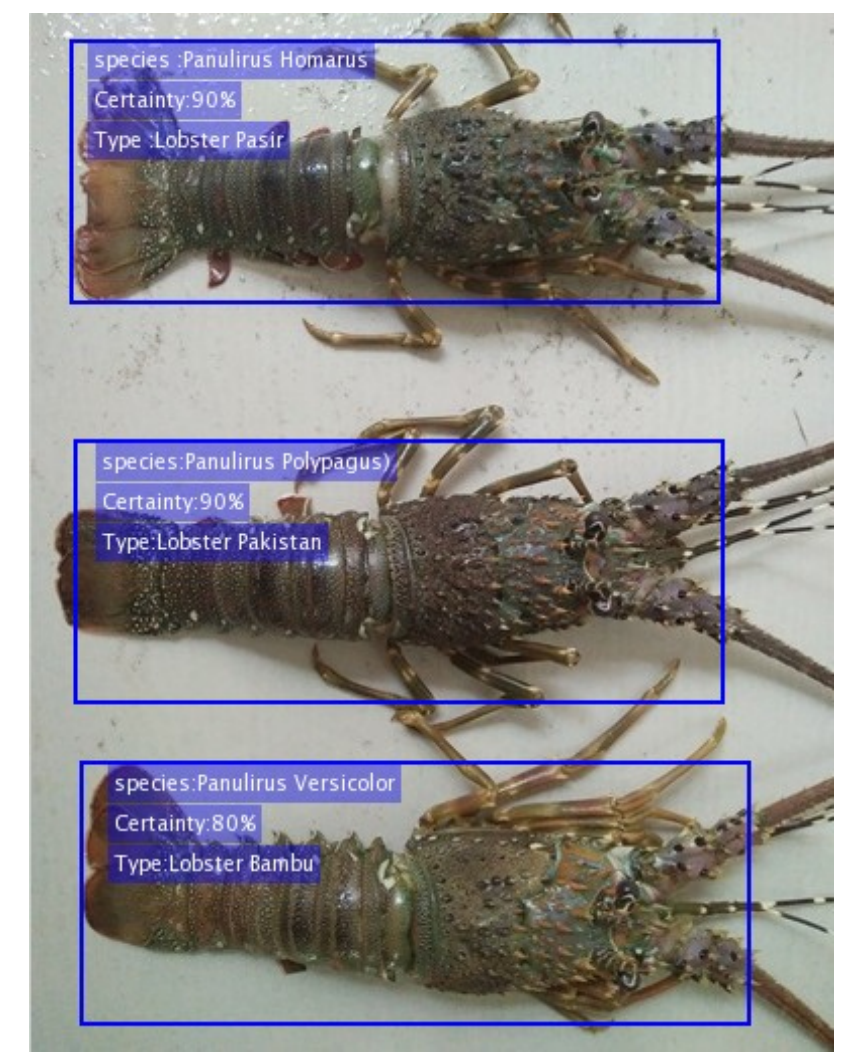

\section{Keterangan :}

Gambar 12. Hasil Identifikasi

Pada gambar 12 diatas adalah hasil pengujian sistem dengan menggunakan tiga jenis lobster yang samplenya digunakan secara acak. Dari hasil pengujian lobster bisa dikenali oleh aplikasi, algorithm computer vision mengenali jenis lobster. Uji coba tersebut diatas terlihat tiga jenis species lobster yaitu jenis lobster bambu, lobster pakistan dan lobster pasir dengan tingkat akurasi masing-masing antara 80\% dan 90\%. Sistem pengenalan dengan algorithm computervision ini terbukti dapat membantu mengenali jenis lobster dengan bantuan kamera yang akan digunakan sebagai alat observasi.

\section{KESIMPULAN}

Penerapan Computer Vision memungkinkan digunakan untuk melihat dan menjaga kesehatan serta perilaku lobster. Jenis lobster yang sehat sendiri dilihat dari ukuran yang besar dan bentuk sirip yang sempurna serta aktif. Sistem monitoring biasanya dilakukan secara konvensional, metode ini tidak akurat bahkan terkadang kita bisa salah mengidentifikasi jenis lobster yang mengakibatkan kesalahan dalam perawatan dan pemberian pakan. Dengan bantuan komputer, sistem identifikasi dapat dilakukan secara tepat dimana lobster sendiri terdapat ciri unik dan tidak dapat dilihat dengan mata telanjang. Tiap data lobster akan tersimpan pada database yang dapat digunakan untuk monitoring selanjutnya. Dengan menggunakan teknik image processing data lobster mampu diidentifikasi dan menampilkan warna yang unik yaitu warna pada lobster dengan warna bintik kemerahan yang berbeda pada tiap lobster.

\section{DAFTAR PUSTAKA}

[1] Patrick, P.H.; N. Ramani; W.G. Hanson;H. Anderson, "The Potential Of A Neural Network Based Sonar System In Classifying Fish," IEEE Conference on Neural Networks for Ocean Engineering, pp. 207 -213, 1991.

[2] M. BENCO; R. HUDEC, "Novel Method for Color Textures Features Extraction Basedon GLCM," RADIOENGINEERING, vol. 16, no. 4, pp. 64-67, 2007.

[3] Matthew Tscharke; Thomas M. Banhazi;, "A brief review of the application of machine vision in livestock behaviour," Journal of Agricultural Informatics, vol. 7, no. 1, pp. 23-42, 2016.

[4] J. Vie, C. Hilton-Taylor, S. Stuart, I.-T. W. C. Union, and I. S. S., "Wildlife in a changing world: An analysis of the 2008 iucn red list of threatened species," IUCN, 2019.

[5] J. M. Rowcliffe ; C. Carbone,, "Surveys using Camera Traps: Are We Looking to a Brighter Future?," Animal 
Conservation," 11, vol. 3, pp. 185 - 186, 2008.

[6] Alexander Gomez Villa; Augusto Salazar ; Francisco Vargas, "Towards automatic wild animal monitoring: Identification of animal species in camera-trap images using very deep convolutional neural networks," Ecological Informatics, vol. 41, pp. 24-32, 2017.

[7] Liu, B.; Zhu, W.; "Segmentation improvement of pig contour based on registration and fusion of IR thermal and optical images.," In 2013 Ninth International Conference on Natural Computation (ICNC), p. 1424-1428, 2013.

[8] Zhu, Q.; Ren, J.; Barclay, D.; McCormack, S.; Thomson, W, "Automatic Animal Detection from Kinect Sensed Images for Livestock Monitoring and Assessment," IEEE International Conference on Computer and Information Technology Ubiquitous Computing and Communications; Dependable, Autonomic and Secure Computing Pervasive Intelligence and Computing, p. 1154-1157.

[9] Zhang, H.; Wei, Q.; Kang, M., "Measurement of swimming pattern and body length of cultured Chinese sturgeon by use of imaging sonar," Aquaculture, vol. 434, p. 184-187, 2014.

[10] Adelson, Edward H.; Charles H. Anderson; James R. Bergen;Burt Joan M. Ogden; Peter J., "Pyramid methods in image processing," RCA engineer, vol. 6, no. 33, pp. 33-41, 1984.

[11] Papadakis, V.M.; Papadakis, J.E.; Lamprianidou, F.; Glaropoulos, A.; Kentouri, M., "A computer-vision system and methodology for the analysis of fish behavior," Aquac. Eng., vol. 46, p. 53-90, 2012.

[12] M. Riedmiller ; H. Braun, "A direct adaptive method of faster backpropagation learning: The rprop algorithm," in IEEE Intern Interna- tional Conference on Neural Networks San Francisco, p. 586-591, 1993. 